\title{
ХРОНИКА
}

DOI: $10.17805 /$ trudy.2015.2.5

\section{I АКАДЕМИЧЕСКИЕ ЧТЕНИЯ ПАМЯТИ ВЛАДИМИРА АНДРЕЕВИЧА ЛУКОВА «МИРОВАЯ КУЛЬТУРА В РУССКОМ ТЕЗАУРУСЕ»}

\author{
Вал. А. Луков \\ (Московский гуманитарный университет)
}

Аннотация: В статье представлен обзор работы I Академических чтений памяти Владимира Андреевича Лукова «Мировая культура в русском тезаурусе», которые прошли в Московском гуманитарном университете 27 марта 2015 г.

Ключевые слова: Владимир Андреевич Луков, МосГУ, ИФПИ МосГУ, академические чтения, обзор, тезаурусная концепция.

\section{“WORLD CULTURE IN THE RUSSIAN THESAURUS" - 1ST ACADEMIC READINGS IN THE MEMORY OF VLADIMIR ANDREYEVICH LUKOV}

\author{
Val. A. Lukov \\ (Moscow University for the Humanities)
}

\begin{abstract}
The article presents a summary of the 1st academic readings in the memory of Vladimir Andreyevich Lukov, which took place at the Moscow University for the Humanities on March 27, 2015, and focused on the general issues of world culture as reflected in the Russian thesaurus.

Keywords: Vladimir Andreyevich Lukov, Moscow University for the Humanities, Institute for Fundamental and Applied Studies, academic readings, summary, thesaurus concept.

27 марта 2015 г. в Московском гуманитарном университете прошли I Академические чтения памяти Владимира Андреевича Лукова, организованные Институтом фундаментальных и прикладных исследований МосГУ и Русской секцией Международная академия наук (IAS, Инсбрук, Австрия).

Вл. А. Луков (1948-2014) - выдающийся русский филолог, культуролог, энциклопедист, последние 10 лет своей жизни работавший в МосГУ, где он возглавлял Центр теории и истории культуры Института фундаментальных и прикладных исследований. Тема Академических чтений отразила основную направленность его научно-исследовательской рабо-
\end{abstract}


ты - «Мировая культура в русском тезаурусе».

С основным докладом выступил директор Института фундаментальных и прикладных исследований Московского гуманитарного университета, вице-президент Международной академии наук (IAS), профессор Вал. А. Луков. Он осветил роль Вл. А. Лукова в становлении тезаурусной методологии гуманитарных исследований, получившей в последнее время широкое распространение в гуманитарных науках.

Заместитель заведующего кафедрой всемирной литературы Московского педагогического государственного университета профессор В.П.Трыков представил результаты исследований Вл. А. Лукова в области филологии за почти полувековой период.

О Владимире Андреевиче Лукове как ученом-гуманитарии, преподавателе, создателе продуктивных научных концепций говорили членкорреспондент РАН, главный научный сотрудник Института философии РАН Б. Г. Юдин, доктор философских наук, профессор, президент Гуманитарно-социального института, профессор Т. Ф. Кузнецова, заведующий кафедрой всемирной литературы Московского педагогического государственного университета, профессор М. И. Никола. Исследования с применением тезаурусного подхода представили академик Российской академии социальных наук А.Н.Свалов, ученый секретарьШекспировской комиссии РАН, доктор философии $(\mathrm{PhD}) \mathrm{H}$. В. Захаров, доцент Уральского федерального университета им. первого Президента России Б.Н.Ельцина (г. Екатеринбург) Н. А. Завьялова и другие участники чтений.

Противостоянию социокультурных кодов в связи с проблемой преодоления западоцентризма в социально-исторических исследованиях было посвящено выступление директора Центра русских исследований Института фундаментальных и прикладных исследований Московского гуманитарного университета А. И. Фурсова, современным исследованиям национальных менталитетов - выступление заместитель руководителя Сектора социальной философии Института философии РАН Г. Ю. Канарша, концептуальному анализу как методу изучения политики - выступление профессора кафедры анализа социальных институтов НИУ ВШЭ В. Г. Ледяева.

В чтениях участвовали директор научно-образовательного центра «Гражданское общество и социальные коммуникации» Института государственной службы и управления ФГБОУ ВПО «Российская академия народного хозяйства и государственной службы при Президенте Российской Федерации», профессор О. Н. Астафьева, профессор ОУК философии и религиоведения Московского городского педагогического университета И. А. Бирич, профессор кафедры философии, культурологии и политологии Московского гуманитарного университета Т. А. Горелова, доцент той же кафедры А. А. Зедгенидзе, заместитель директора Гуманитарно- 
прикладного института НИУ «МЭИ» К. Н. Кислицын, проректор по учебной работе Московского гуманитарного университета, профессор А. И. Ковалева, главный научный сотрудник Института проблем информатики РАН, профессор К. К. Колин, декан факультета культуры и искусства, заведующий кафедрой философии, культурологии и политологии Московского гуманитарного университета, профессор А. В. Костина, заместитель директора Института фундаментальных и прикладных исследований Московского гуманитарного университета Ч. К. Ламажаа, докторант кафедры истории и теории культуры факультета истории искусства Российского государственного гуманитарного университета И. И. Лисович, декан факультета международных отношений и туризма Московского гуманитарного университета, профессор Г. П. Хорина, заместитель руководителя экспертно-аналитического Центра развития образовательных систем в сфере культуры Института культурного и природного наследия им. Д. С. Лихачева, профессор Е. Н. Шапинская, руководители центров ИФПИ МосГУ Б. Н. Гайдин, С. В. Луков, В. С. Макаров, профессора Б. А. Ручкин, И. Г. Яковлев, преподаватели, аспиранты, студенты Московского гуманитарного университета и других вузов Москвы. В чтениях участвовали также сыновья Вл. А. Лукова Михаил и Андрей, защитившие в МосГУ кандидатские диссертации.

Организаторы Академических чтений предусматривали работу и в заочном режиме. К началу чтений пришли материалы из Иркутска, Кирова, Орска, Самары, Симферополя, Ставрополя и других российских городов, а также из Одессы (Украина).

Луков Валерий Андреевич - доктор философских наук, профессор, заслуженный деятель науки РФ, директор Института фундаментальных и прикладных исследований Московского гуманитарного университета, вице-президент Международной академии наук (IAS, Инсбрук, Австрия). Адрес: 111395, Россия, г. Москва, ул. Юности, д. 5. Тел.: +7 (499) 374-70-20. Эл. адрес: v-lukov@list.ru

Lukov Valery Andreevich, Doctor of Philosophy, Professor, Director, Institute of Fundamental and Applied Studies, Moscow University for the Humanities; Honored Scientist of the Russian Federation; Vice President, International Academy of Science (Innsbruck, Austria). Postal address: 5 Yunosti St., 111395 Moscow, Russian Federation. Tel.: +7 (499) 374-70-20. E-mail:v-lukov@list.ru 